\title{
ATTACHMENT OF NYMPHAL RHIPICEPHALUS SANGUINEUS (ACARI: IXODIDAE) TO A HUMAN IN AN URBAN AREA FOLLOWED BY SEVERE ADVERSE REACTION SHORTLY BEFORE DROP-OFF
}

\author{
Igor Uspensky
}

A. Silberman Institute of Life Sciences, The Hebrew University of Jerusalem, Jerusalem, 91904, Israel

\begin{abstract}
A case of attachment and complete engorgement of a Rhipicephalus sanguineus (Latreille, 1806) nymph on a woman with severe pain shortly before nymphal drop-off is described. The pain continued for about 2 weeks after tick removal. Apparently, this is the first documented case of human adverse reaction developed at the very last stage of engorgement of nymphal $R$. sanguineus. The infestation most likely took place inside the enclosed household garden in the southern area of Jerusalem where the woman took care of the plants. The importance of immature $R$. sanguineus ticks in attacking humans is discussed.
\end{abstract}

The brown dog tick (or kennel tick) Rhipicephalus sanguineus (Latreille, 1806) has great medical and veterinary significance, being the vector and reservoir of many human and animal pathogens (Walker et al. 2000, Parola and Raoult 2001, Uspensky 2008). Dogs are the main hosts of both adult and preadult parasitic stages of the tick. Adult $R$. sanguineus can also feed on many other mammals, such as goats, sheep, cattle, horses, ungulates, wild carnivores, cats, hares and hedgehogs; preadult ticks were found on shrews and many rodents (Filippova 1997, Walker et al. 2000). Ticks in all parasitic stages can also attack and bite humans though $R$. sanguineus is not considered by many authors as having a close affinity to humans (Nelson 1969, Walker et al. 2000, Parola and Raoult 2001, Parola 2004). There is even a statement in some text-books that this tick does not bite humans at all (Randall 1998).

The case described below took place in the southern area of Jerusalem in early September. Late at night, a woman of 67 suddenly felt terrible pain in the back part of her right shoulder. With the aid of the mirror she saw a tick attached to her body at the site of pain. She tried to remove the tick but could only take off the main part of the body (idiosoma), which she preserved. The tick hypostome imbedded in the cement substance was left in her shoulder. At the tick attachment site the woman felt some formation. She tried to remove this formation and succeeded during the next day. During the next days, the woman constantly felt pain in her right shoulder, which was very strong when moving her right hand. The area of tick attachment looked very inflamed and reddish. The pain continued to increase when moving her right hand and especially under a hot shower. Because of the pain, the woman could not sleep on her right side.

Ten days after the event took place, the inflammation and redness were absent and only two uneven injuries on the skin, about
$1 \mathrm{~cm}$ apart, were seen in the area of tick attachment. The woman still felt some pain but much less than in the beginning. The pain completely disappeared 2 weeks after the event. Regretfully, the woman did not visit her doctor and make any blood tests. The remains of the tick body were identified by I. Ioffe-Uspensky as the engorged nymph of $R$. sanguineus ready to drop-off. The duration of nymphal feeding in this species is about 4 days (Ioffe-Uspensky et al. 1997). The woman had never previously been bitten by $R$. sanguineus but in her youth when she worked in the Southern Ural Mountains (Russia), she was bitten couple of times by adult Ixodes persulcatus Schulze, 1930 without any adverse reaction.

Rhipicephalus sanguineus is included in the list of tick species that have been implicated in causing toxicosis in their hosts but for which neither conclusive experimental data (Mans et al. 2004) nor conclusive reports on cases with humans (MüllerDoblies and Wikel 2005) exist. The indication that the secretion of neurotoxin coincides with a definite repletion phase is limited to female ticks only and has nothing to do with our case dealing with a nymphal tick. To my knowledge, no significant data concerning any human adverse reaction after $R$. sanguineus attachment have been reported. The statement that $R$. sanguineus "has been found to contain the toxin which produces tick paralysis in humans" (Masters 1960) is unsupported by evidence. Human anaphylaxis caused by Rhipicephalus ticks bites in Spain (Acero et al. 2003, Valls et al. 2007) cannot be reliably attributed to $R$. sanguineus since there are three species of Rhipicephalus in the country that can attack people ( $R$. sanguineus, $R$. turanicus Pomerantsev, 1936 and R. bursa Canestrini et Fanzago, 1878). In the first of these papers the tick was classified as Rhipicephalus sp. while the identification of the ticks as $R$. sanguineus in the second paper was questioned by Dantas-Torres (2008). The elucidation of the authors that the ticks identified as $R$. sanguineus parasitized goats (Valls 2008), which is more typical of $R$. bursa, only increases doubts on the correctness of identification.

Thus, in the case described, severe pain after $R$. sanguineus nymph attachment that appeared at the very last stage of nymphal engorgement and continued for 2 weeks after tick removal seems to be the first documented event of its kind. The response cannot be explained by infection related to the tick's hypostome left in the woman's body since the pain appeared earlier and only because of this pain was the woman able to find the tick. It is impossible to say whether the woman's reaction is an allergic

Address for correspondence: I. Uspensky, Department of Biological Chemistry, A. Silberman Institute of Life Sciences, The Hebrew University of Jerusalem, Givat-Ram Campus, Jerusalem 91904, Israel. Phone: +972 2645 0056; Fax: +972 26586448 (to Dr. I. Uspensky);

E-mail: igorusp@vms.huji.ac.il 
one or due to the toxic components of tick secretory products. Apparently, such a response is very rare. The presence of two similar injuries near each other may indicate that there were two nymphs attached, one of which dropped-off earlier without causing any reaction.

The woman and her husband occupy a large flat on the ground floor of a 4-story building. There is an exit from the flat to a small, enclosed garden (about $120 \mathrm{~m}^{2}$ ), which has a wire netting fence with a fairly large mesh size. The woman is a gardening enthusiast and every day goes out into the garden to take care of the plants. For several days previous to the event, she left the flat only for the garden. The couple has not had a dog for 5 years but there are a number of domesticated dogs in the vicinity. Several years ago there were many hedgehogs in the area. However, many stray cats have appeared in the area during recent years and the hedgehogs have disappeared. The cats regularly go into the garden and even try to penetrate the flat.

The woman's infestation most likely took place inside the enclosed garden. Gardening activities even in urban areas can be a cause of human infestation by ticks (McLaughlin 2002, Gritsun et al. 2003). Unfed nymphs molted from engorged larvae could be dropped-off from the dogs and crawled for several metres inside the garden. Urban rodents could also be a source of dispersal for immature ticks. One more possibility may be connected with stray cats that recently became the main pests in the area. There is an opinion that because of their fastidious grooming habits cats are rarely infested with ticks (Irwin and Jefferies 2004). However, data on cat infestation with ticks in different regions have regularly appeared (Ogden et al. 2000, González-Acuña and Guglielmone 2005, Nijhof et al. 2007). The persistence of stray cats in penetrating into household gardens and human dwellings followed by tick attachment to a human was recorded by Shimizu et al. (2000). Cats are known as hosts of $R$. sanguineus (Filippova 1997). They are regularly parasitized by this tick inside its reproductive range, especially in areas frequented by dogs.

Rhipicephalus sanguineus has been considered by many authors as a species which rarely attack humans. In the recent most comprehensive monographs concerning Rhipicephalus (Filippova 1997, Walker et al. 2000), man is mentioned as a possible host of the tick but only of the adult stage. However, cases of nymphal and even larval $R$. sanguineus attacks on humans have been documented in a number of publications. In the USA such facts were mentioned, among others, by Carpenter et al. (1990), Slaff and Newton (1993), Campbell and Bowles (1994), Harrison et al. (1997), Merten and Durden (2000). In Europe such attacks were mainly documented in the Mediterranean (Gilot et al. 1990, Manfredi et al. 1999, personal observations). An extreme case of multiple nymphal attacks on a homeless man in Marseille followed by his death from Mediterranean spotted fever (MSF) was described by Hemmersbach-Miller et al. (2004). Preadult tick attacks on humans are also known from Africa and Asia (Dilrukshi et al. 2004, Okoli et al. 2006). In addition, the correlation found between the time of the highest prevalence of immature ticks and human morbidity by MSF (Gilot et al. 1990) shows that the epidemiological importance of preadult $R$. sanguineus has been underestimated.

Undoubtedly, this tick has an obvious preference for dogs as hosts in all developmental stages. In urban areas, the occurrence of the ticks and human cases of tick-transmitted diseases are closely connected with the presence of dogs (Tringali et al. 1986, Wilamowsky et al. 1999, Uspensky and Ioffe-Uspensky 2002, Mouffok et al. 2006). However, when dogs are absent [or treated with acaricide (Černý 1985) or repellents (Parola 2004)], $R$. sanguineus can attack many other hosts including humans. According to my own observations (unpublished), adult ticks in Israel attack people very aggressively either in the field when dogs are absent or under conditions of very high tick density even when dogs are available as hosts. As for unfed preadults, they can easily be overlooked because of their small size. It was shown that the size of $R$. sanguineus preadults is among the smallest as compared with other tick species (Ioffe-Uspensky et al. 1997, Uspensky et al. 1999). An important point is that an attached tick is not disturbed by showering or bathing (Uspensky et al. 1997, Shimizu et al. 2000) as happened in the case described above.

I am most grateful to Dr. H.J. Schnur for her excellent linguistic assistance.

\section{References}

Acero S., Blanco R., Bartolomé B. 2003: Anaphylaxis due to a tick bite. Allergy 58: 824-825.

Campbell B.S., Bowles D.E. 1994: Human tick bite records in a United States Air Force population, 1989-1992: implications for tick-borne disease risk. J. Wilderness Med. 5: 405-412.

Carpenter T.L., McMeans M.C., McHugh C.P. 1990: Additional instances of human parasitism by the brown dog tick (Acari: Ixodidae). J. Med. Entomol. 27: 1065-1066.

ČERNÝ V. 1985: First case of introduction of the tick Rhipicephalus sanguineus to Czechoslovakia. Folia Parasitol. 32: 162.

Dantas-Torres F. 2008: Anaphylactic shock caused by tick bites. J. Investig. Allergol. Clin. Immunol. 18: 231

Dilrukshi P.R.M.P., Yasawardene A.D.K.S.N., Amerasinghe P.H., Amerasinghe F.P. 2004: Human otoacariasis: a retrospective study from an area of Sri Lanka. Trans. R. Soc. Trop. Med. Hyg. 98: 489-495.

FilipPova N.A. 1997: [Ixodid Ticks of the Subfamily Amblyomminae. Arachnoidea 4(5). Fauna of Russia and Neighbouring Countries]. "Nauka" Publishing House, St. Petersburg, Russia, 436 pp. (In Russian.)

Gilot B., Laforge M.L., Pichot J., Raoult D. 1990: Relationships between the Rhipicephalus sanguineus complex ecology and Mediterranean spotted fever epidemiology in France. Eur. J. Epidemiol. 6: 357-362.

GonzÁlez-Acuña D., Guglielmone A.A. 2005: Ticks (Acari: Ixodoidea: Argasidae, Ixodidae) of Chile. Exp. Appl. Acarol. 35: 147-163.

Gritsun T.S., Lashrevich V.A., Gould E.A. 2003: Tick-borne encephalitis. Antivir. Res. 57: 129-146.

Harrison B.A., Engber B.R., Apperson C.S. 1997: Ticks (Acari: Ixodida) uncommonly found biting humans in North Carolina. J. Vector Ecol. 22: 6-12.

Hemmersbach-Miller M., Parola P., Raoult D., Brouqui P. 2004: A homeless man with maculopapular rash who died in Marseille, France. Clin. Infect. Dis. 38: 1493-1494.

Ioffe-Uspensky I., Mumcuoglu K.Y., Uspensky I., Galun R. 1997: Rhipicephalus sanguineus and $R$. turanicus (Acari: Ixodidae): closely related species with different biological characteristics. J. Med. Entomol. 34: 74-81.

IRWIN P.J., JefFeries R. 2004: Arthropod-transmitted diseases of companion animals in Southeast Asia. Trends Parasitol. 20: 27-34. 
Manfredi M.T., Dini V., Piacenza A.S., Genchi C. 1999: Tick species parasitizing people in an area endemic for tick-borne diseases in north-western Italy. Parassitologia 41: 555-560.

Mans B.J., Gothe R., Neitz A.W.H. 2004: Biochemical perspectives on paralysis and other forms of toxicosis caused by ticks. Parasitology 129: S95-S111.

Masters C.O. 1960: Arthropods of medical importance in Ohio. Ohio J. Sci. 60: 332-334.

McLaughlin J. 2002: Gardens as a source of infectious disease: reducing the risk. Miami Dade County Extension Service, 25 pp. (Available online: http://miami-dade.ifas.ufl.edu/pdfs/urban_hort/Gardening-Infectious-Disease.PDF)

Merten H.A., Durden L.A. 2000: A state-by-state survey of ticks recorded from humans in the United States. J. Vector Ecol. 25: $102-113$

Mouffok N., Benabdellah A., Richet H., Rolain J.M., Razik F., Belamadani D., Abidi S., Bellal R., Gouriet F., Midoun N., Brouqui P., RAoult D. 2006: Reemergence of rickettsiosis in Oran, Algeria. Ann. N.Y. Acad. Sci. 1078: 180-184.

Müller-Doblies U.U., WiKel S.K. 2005: The human reaction to ticks. In: J.L. Goodman, D.T. Dennis and D.E. Sonenshine (Eds.), Tick-Borne Diseases of Humans. ASM Press, Washington, D.C., pp. 102-122.

NeLson V.A. 1969: Human parasitism by the brown dog tick. J. Econ. Entomol. 62: 710-712.

Nijhof A.M., Bodaan C., Postigo M., Nieuwenhuijs H., Opsteegh M., Franssen L., Jebbink F., Jongejan F. 2007: Ticks and associated pathogens collected from domestic animals in the Netherlands. Vector-Borne Zoonot. Dis. 7: 585-595.

Ogden N.H., Cripps P., Davidson C.C., Owen G., Parry J.M., Timms B.J., Forbes A.B. 2000: The ixodid tick species attaching to domestic dogs and cats in Great Britain and Ireland. Med. Vet. Entomol. 14: 332-338.

Okoli I.C., Okoli C.G., Opara M. 2006: Environmental and multi-host infestation of the brown dog tick, Rhipicephalus sanguineus in Owerri, south-east Nigeria - a case report. Vet. Arh. 76: $93-100$.

PAROLA P. 2004: Tick-borne rickettsial diseases: emerging risks in Europe. Comp. Immunol. Microbiol. Infect. Dis. 27: 297-304.

Parola P., Raoult D. 2001: Ticks and tickborne bacterial diseases in humans: an emerging infectious threat. Clin. Infect. Dis. 32: 897-928.

RANDALl C. 1998: Urban Integrated Pest Management. A Guide for Commercial Applicators. Michigan State University, Extension Bulletin E-2048, 232 pp.
Shimizu I., Mitani H., Shono M., Omoya T., Musashi Y., Sannomiya K., Suzuki M., Horie T., Honda H., Ito S. 2000: An incident involving blood sucking by a tick in a suburb in Japan. J. Med. Investig. 47: 145-147.

Slaff M., Newton N.H. 1993: Location of tick (Acari: Ixodidae) attachment sites on humans in North Carolina. J. Med. Entomol. 30: 485-488.

Tringali G., Intonazzo V., Perna A.M., Mansueto S., Vitale G., Walker D.H. 1986: Epidemiology of boutonneuse fever in western Sicily. Distribution and prevalence of spotted fever group rickettsial infection in dog ticks (Rhipicephalus sanguineus). Am. J. Epidemiol. 123: 721-727.

USPENSKY I. 2008: Brown dog tick (or kennel tick), Rhipicephalus sanguineus (Latreille) (Acari: Ixodida: Ixodidae). In: J.L. Capinera (Ed.), Encyclopedia of Entomology, Vol. 1. Second Edition. Springer, Dordrecht, pp. 577-580.

USPENSKY I., IOFFE-UsPENSKY I. 2002: The dog factor in brown dog tick Rhipicephalus sanguineus (Acari: Ixodidae) infestations in and near human dwellings. Int. J. Med. Microbiol. 291 (Suppl. 33): $156-163$.

Uspensky I., Ioffe-Uspensky I., Mumcuoglu K.Y., Galun R. 1999: Body weight characteristics of some ixodid ticks: Reflecting adaptations to conditions of their habitats? In: J. Bruin, L.P.S. van der Geest and M.W. Sabelis (Eds.), Ecology and Evolution of the Acari. Kluwer Academic Publishers, Dordrecht, pp. 657665.

Uspensky I., Wilamowski A., Bromley-Schnur H. 1997: Dermacentor variabilis in Israel. Vector Ecol. Newsl. 28(3): 9-10.

VaLls A. 2008: Species identification of Rhipicephalus sanguineus. J. Investig. Allergol. Clin. Immunol. 18: 232.

Valls A., Pineda F., Belver M., Caballero T., López M.C. 2007: Anaphylactic shock caused by tick (Rhipicephalus sanguineous). [sic] J. Investig. Allergol. Clin. Immunol. 17: 279280.

Walker J.B., Keirans J.E., Horak I.G. 2000: The Genus Rhipicephalus (Acari: Ixodidae). A Guide to the Brown Ticks of the World. Cambridge University Press, Cambridge, UK, 643 pp.

Wilamowski A., Bromley-Schnur H.J., Ioffe-Uspensky I., UsPENSKY I. 1999: Ticks (Ixodoidea) in Israeli towns. In: Proceedings of the 3rd International Conference on Urban Pests. Czech University of Agriculture, Prague, Czech Republic, pp. 477-483.

Received 8 January 2009

Accepted 23 February 2009 